\title{
Critical exposition of Japanese takeover law in an international context*
}

\begin{abstract}
There is a common perception that the Japanese takeover market excludes foreign companies. But this is not because Japanese takeover law is designed to protect target companies. Comparing Japanese takeover law with the UK Takeover Code and the European Takeover Directive, this thematic and contentbased investigation reveals that Japan does not have overt anti-takeover legislation. There is no stake-building control to alert a target company; there is no provision against virtual bids; post-bid undertaking is not legally binding on the bidder; the equivalent of the mandatory bid under the UK Takeover Code and the EU Directive is set at a much higher level so making it less costly for a bidder to obtain corporate control; there is no price control to protect minority shareholders. Yet the traditional symbiotic relationship between management and shareholders through cross-shareholdings and shareholder perks remains a major obstacle to a successful unsolicited takeover. Measures have been introduced to increase the success of unsolicited takeover bids by reducing cross-shareholdings through tax incentive measures and increasing board independence through a soft-law based governance code. These are unlikely to have a major impact on removing the existing obstacles. Adopting the UK Takeover Code or the EU Takeover Directive would not cure the problem and would more likely entrench the existing situation.
\end{abstract}

\section{The aim and the methods used to set Japan's takeover regime in context}

Japan, as the third-largest economy and second-largest capital market in the world $^{1}$, has been regarded as a difficult market for foreign companies to penetrate compared with other advanced economies. ${ }^{2}$ Domestically, the economy's slow growth has led to calls for reform of its rigid structure, which often inhibits the entrepreneurial spirit. ${ }^{3}$ The aim of this paper is to see if converging with UK and EU takeover laws would permit more unsolicited takeover bid. To this end, this paper uses Japan's primary takeover law, the Financial Instrument and Exchange Law (FIE), as a proxy to understand Japan's perceived protectionist model, which is designed to protect corporate value,

\footnotetext{
- Joseph Lee, PhD (London), Senior lecturer in law, University of Exeter (UK); Visiting Professor, National Taiwan University (Taiwan); Principal Investigator, The British Academy (UK).

1 With regard to market capitalization, the LSE, the fourth largest capital market in the world, stood at 4.09 Trillion GBP in December 2014.

2 Simon Bytheway 'Liberalisation, internationalisation, and globalization: charting the course of foreign investment in the finance and commerce of Japan, 1945-2009' (2010) 22(3) Japan Forum 433-465; Ralph Paprzycki and Kyoji Fukao Foreign direct investment in Japan: Multinational's Role in Growth and Globalization (CUP Cambridge 2008).

3 Jennifer Amyx Japan's Financial Crisis: Institutional Rigidity and Reluctant Change (2004, Princeton University Press Princeton NJ 2004).
} 
existing shareholders, stakeholders, and community value. ${ }^{4}$ However, it is evident that the law itself does not reveal much about Japan's protectionist tendencies; that some contextualisation is necessary. ${ }^{5}$ Hence, the article uses the following methods to provide the appropriate context.

First, the paper will examine the ownership structure of the companies listed on the Tokyo Stock Exchange (TSE), the recent changes to the TSE and the way it differs from other major markets. ${ }^{6}$ Second, the article will investigate Japan's methods for corporate control, as measured by the different methods used to transfer it. Third, a thematic and content-based approach will be used to examine the FIE. The themes examined will include stake-building control, virtual bid control, commitment control, mandatory bids, and defensive measures control. The purpose of these regulatory aspects will be discussed, followed by a discussion of Japan's rules and the implications of their implementation. Other jurisdictions, notably the UK and EU, will also be compared. Fourth, an increase in unsolicited takeover bids in recent years correlates with a decrease in cross-shareholding. The factors that have led to this change will be identified, in particular the growing participation of hedge funds as third-party facilitators of takeovers of poorly performing firms in corporate Japan. ${ }^{7}$ Fifth, Japan's corporate governance will be analysed in order to assess whether changes to the role of independent directors and the types of shareholder protection could allow more outside and unsolicited takeovers.

\section{Japan's capital market structure}

\section{Ownership structure}

Japan has been regarded as a capital market that is foreclosed to foreign capital regarding the ability to gain access and corporate control of Japanese companies. The statistics show that foreign capital owns approximately 32 per cent of the shares traded on the Tokyo Stock Exchange (TSE), compared with approximately 50 per cent on the London Stock Exchange (LSE). However, the difficulty in gaining access to corporate control should not suggest a lack of internationalisation in Japan's capital market. ${ }^{8}$ Compared with other major European capital markets, such as those of France, Germany and Italy, Japan remains an attractive market for foreign investors. The holdings of Japan's domestic banks in the capital market are approximately 23 per cent of the total

\footnotetext{
${ }^{4}$ Ulrike Schaede 'From developmental state to the 'New Japan': the strategic inflection point in Japanese business' (2012) 18(2) Asia Pacific Business Review 167-185.

5 Jonathan Morris, John Hassard, Leo McCann 'The resilience of 'institutionalised capitalism': Managing managers under 'shareholder capitalism' and 'managerial capitalism' (2008) 61(5) Human Relations 687-710.

${ }^{6}$ Shinhua Liu, John Stowe, Ken Hung 'Why US firms delist from the Tokyo stock exchange: An empirical analysis' (2012) 24(1) International Review of Economics \& Finance 62-70.

${ }^{7}$ John Buchanan, Dominic Heesang Chai, and Simon Deakin Hedge Fund Activism in Japan: The Limits of Shareholder Primacy (CUP Cambridge 2012).

${ }^{8}$ Kee-hong bae, Takeshi Yamada, Keiichi Ito, 'How do individual, institutional, and foreign investors win and lose in equity trade? Evidence from Japan' (2006) 6(3) International Review of Finance 129-155.
} 
market share, which is not significantly less than the amount held by UK institutional shareholders in the LSE, which is currently approximately 30 per cent. ${ }^{9}$ Domestic companies, not including financial institutions, hold approximately 22 per cent of the total market share in the TSE. Cross-held shares, not common in the UK and US, are owned by banks and domestic companies. As such, a block of almost 50 per cent of shares in the total market acts as an effective control mechanism for corporate Japan. In addition, individual/retail investor ownership has decreased, following the same path as the UK, ${ }^{10}$ from approximately 20 per cent in 1990 to approximately 17 per cent in 2013. The government's holdings have remained steady at a marginal rate of 0.2 per cent, compared with European stock markets' state ownership of approximately 4 per cent. ${ }^{11}$

There has also been a significant increase in foreign ownership of Nikkei 225 companies. In 1990, foreign shareholders owned approximately 5 per cent of the Nikkei 225 companies, but by 2014, foreign ownership rose to a staggering 32 per cent. This increase stands in sharp contrast to the decline in ownership by city and regional banks, which coincided with Japan's reform initiatives, including the introduction of the Securities and Exchange Law, Japan's primary takeover legislation ${ }^{12}$, and efforts by the government to buy cross-held shares in a special fund that sold to private equity firms. Since then, Japan has experienced a wave of corporate takeovers, including unsolicited hostile takeovers. ${ }^{13}$

The market for corporate control

The current market for corporate control in Japan is one of the most active in advanced economies as measured by the total number of M\&A activities. Before the 2008 financial crisis, there were 2,776 merger and acquisition deals. ${ }^{14}$ In

${ }_{9}^{9}$ Office for National Statistics, UK. Family holdings of companies in the UK are low. See also Julian Franks and others 'Ownership: evolution and Regulation' (2003) ECGI -Finance Working Paper No. 09/2003. Mutual funds in the UK are significant blockholders. See Philip H Phan and Toru Yoshikawa, 'Corporate governance in Singapore: Developments and Prognoses' (Academy of International Business Annual Meeting, 2004).

${ }^{10}$ UK individuals owned 11.5 per cent of the value of the UK stock market at the end of 2010, which was down from 16.7 per cent in 1998. See Ownership of UK Quoted Shares 1998 and 2010, Office for National Statistics http://www.ons.gov.uk/ons/rel/pnfc1/share-ownership---shareregister-survey-report/2010/stb-share-ownership-2010.html

${ }^{11}$ EU Commission Report, Who Owns the European Economy: Evolution of the Ownership of EUListed Companies between 1972-2012 http://ec.europa.eu/finance/finservicesretail/docs/fsug/papers/1308-report-who-owns-european-economy_en.pdf. Japan does not have holdings by government-linked corporations-an economic model used in Singapore and other developing countries. For instance, 26 of the 100 largest firms listed on the Singapore Exchange (SGX) are controlled to varying degrees by the state through GLCs. See Lay Hong Tan, 'Family Owned Firms in Singapore: Legal Strategies for Constraining Self dealing in concentreated ownership structures' (2011) 23 Singapore Academy of Law Journal 890.

12 See Hiroshi Oda, The Current State of Takeover Law in Japan, (2009) Journal of Business Law.

${ }^{13}$ See the statistics in Enrico Colcera, The Market for Corporate Control in Japan: M\&As, Hostile Takeovers and Regulatory Framework, (Heidelberg 2007), pp40-51.

14 Deloitte 'Deals and Divestitures Trends in Japanese Mergers \& Acquisitions' (October 2014) http://www2.deloitte.com/content/dam/Deloitte/jp/Documents/mergers-and-acquisitions/jpma-ma-newsletter-oct2014-en.pdf; A Metwalli and Roger Tang 'Mergers and acquisitions in Japan: An update' (2013) 24(6) Journal of Corporate Accounting \& Finance 25-34. 
terms of the number of takeover bids made, there are, on average, 70 cases per year ${ }^{15}$, compared with the LSE's average of 115 cases per year. ${ }^{16}$ Japan's market for corporate control is characterised by more outbound than inbound activities, few takeovers by foreign investors, and friendly rather than unsolicited, hostile takeovers. One feature of Japan's market is that there have been no successful foreign takeovers - friendly or hostile-of major Japanese companies ${ }^{17}$, whereas the UK, France, and the US have all experienced foreign takeovers of major companies. This lack of internationalisation of major Japanese companies via foreign takeovers can be attributed to many factors, such as the national sentiment of retail investors, the rigid business practice of cross-shareholding, and legal barriers.

Japan has a dispersed ownership structure that is similar to that of the UK and other advanced economies among the EU member states. It also has a high level of foreign ownership, which does not accord with the perception of a foreclosed capital market. Japan enjoys a high number of takeover offer announcements filed with regulators, which indicates that there is a market for corporate control, although the precise merger and acquisition methods need to be surveyed.

\section{Share Ownership at Market Value 1990 (Source: TSE)}

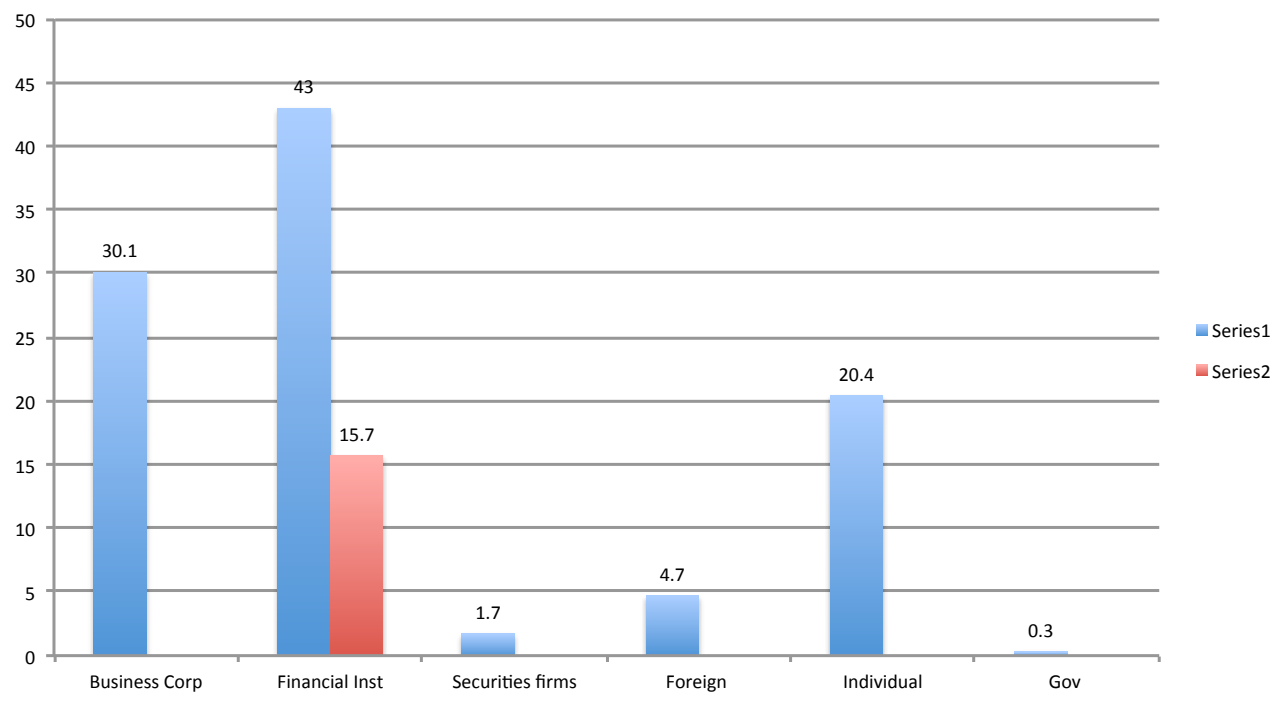

\footnotetext{
15 Tokyo Stock Exchange Report. http://www.jpx.co.jp/english/corporate/investor-relations/irlibrary/annual-reports/

16 UK Takeover Panel Annual Report. http://www.thetakeoverpanel.org.uk/statements/reports

17 There are some foreign takeovers of smaller Japanese companies.
} 


\section{Share Ownership at Market Value 2013 (Source: TSE)".}

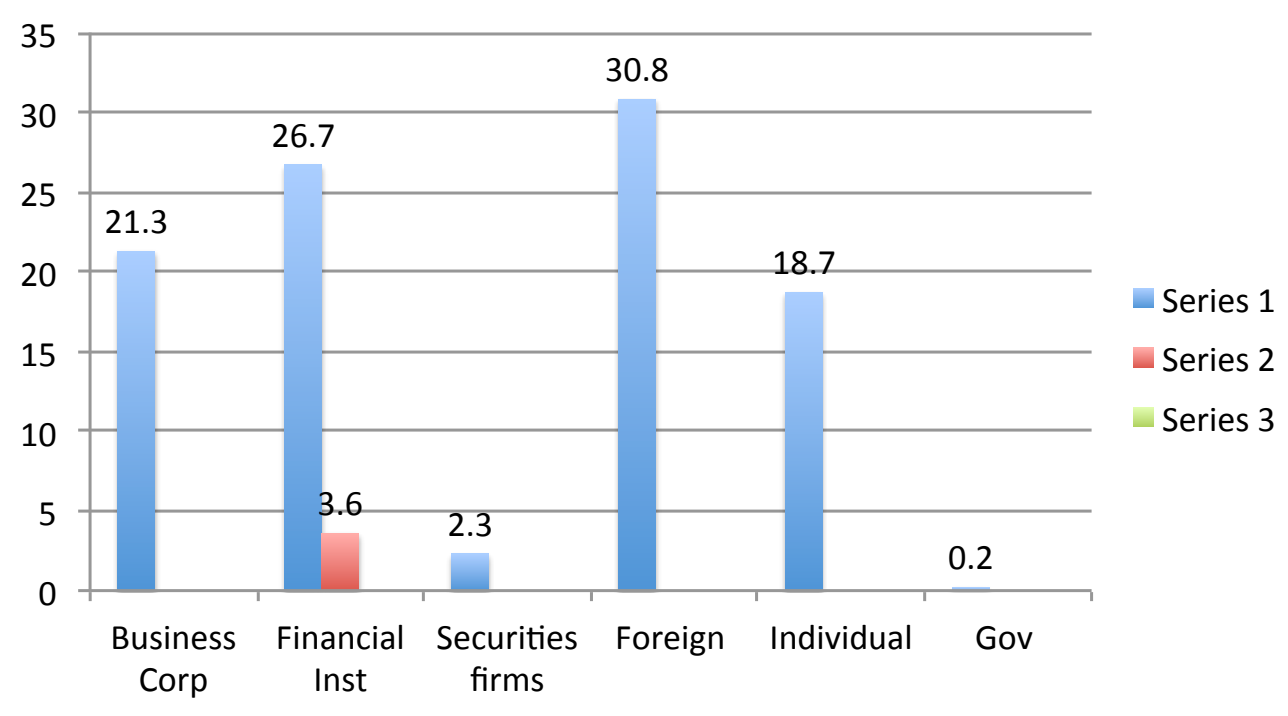

Capital Market Structure in Japan - Number of TOB Notifications

(Source: TSE)

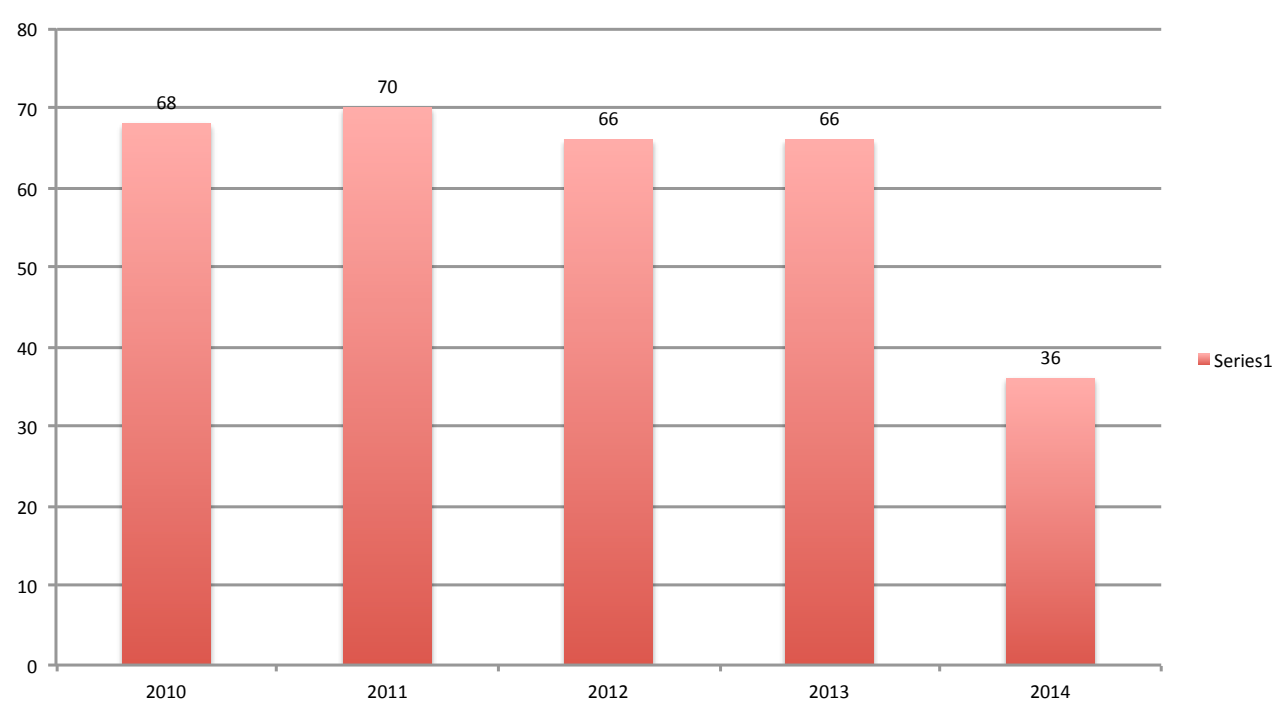




\section{No apparent anti-takeover regulation}

As discussed, the increase in foreign ownership in the Nikkei 225 coincided with the introduction of the FIE, Japan's primary takeover legislation. This paper takes a thematic approach to analyse Japan's takeover law, which consists of the FIE and court-developed rules. A number of regulatory themes can be used to discern whether the rules have an anti-takeover effect and tendency. These themes are stake-building control, virtual bid control, commitment control, mandatory bid requirements, and finally, control of defensive measures.

\subsection{Stake-building control}

Stake-building is a mechanism for an acquirer to acquire control in a company discreetly and without paying a control premium. At the same time, the target company wants to be aware of a potential acquirer building a stake in the company so that it can plan its defence strategies. These strategies can involve bringing the acquirer to the negotiating table or thwarting the acquirer's plan before a takeover becomes imminent. Requiring an acquirer to disclose its stake in the company makes the acquisition process more transparent and allows the target to identify a potential acquirer and monitor its holdings. A 'creeping control' provision essentially restricts the time frame within which a person can obtain statutory control of a company. The FIE requires a person who holds more than 5 per cent of the shares issued by a listed company, whether jointly or with other holders, to file a 'large shareholding report' (LSR) within 5 business days from the date when the shareholding exceeds this threshold. ${ }^{18}$ After such a filing, an increase or decrease by 1 per cent or more requires an amendment to be filed within 5 business days. These provisions result in a burden on a potential acquirer and represent effective control of capital movement by providing information that enables a target company to monitor the position of any potential acquirer. However, there is no significant difference between Japan's requirement for such disclosure and those of the UK and the EU. In fact, the UK's Disclosure Rules and Transparency Rules (DTRs) require a more stringent threshold of 3 per cent. ${ }^{19}$ In addition to the requirement that this disclosure be made to the issuer company, the UK Companies Act 2006 also provides that a company can serve notice on any person whom the company knows or has reasonable cause to believe has an interest in the company's shares or had an interest within the last three years, requiring that person to provide information on the extent of his or her interest. ${ }^{20}$ This includes indirect or beneficial interests in shares or an agreement regarding the purchase of shares where parties are acting in concert. ${ }^{21}$ Where a person fails to comply with such a notice, they commit an offence under the Act. ${ }^{22}$ In addition, the company may apply for an order from the Court restricting the rights attached to the non-

\footnotetext{
18 The FIE, Article 27-2.1.1-6.

19 The Disclosure Rules and Transparency Rules, DTRs 5.1.2.

20 UK Companies Act 2006, s793.

21 UK Companies Act 2006, s 820.

22 UK Companies Act 2006, s 794.
} 
complying person's shares, and such restrictions may include a restriction on voting rights. ${ }^{23}$ In contrast, Japan does not provide such an equivalent power to the target company. The disenfranchisement of non-disclosed shares was specifically ruled out by the Cabinet Office in Japan on a technical ground. ${ }^{24}$ It is possible that a person who plans a stake-building effort may fail to disclose the required information, either intentionally or unintentionally. In this case, the target would have no way of knowing about any on-going stake-building in the company by the bidder alone or acting in concert. In some countries, the central securities depository (CSD) holds information about the identity of shareholders. The Japan Securities Depository Center (JASDEC), Japan's CSD, only notifies a company of its register of members on record dates ${ }^{25}$. Furthermore, as shares of Japanese issuers are mostly held by custodian banks (trust banks), the names of the custodian banks, rather than the end investors ${ }^{26}$, appear on the company's register of members. Thus, a target company cannot easily detect and identify stake-building by a potential predator. In terms of the regulatory control on stake-building, Japan provides less information and power to a target company to detect, monitor, and defend a creeping takeover by an acquirer than the UK. The EU directive provides no regulations on stake-building control.

\subsection{Virtual bid control}

A virtual bid describes a situation when a bidder engages with a target company in making an offer to purchase shares in the company. It has the effect of diverting the attention of the target company, and if the period is prolonged, the uncertainty that results can lead to a substantial cost for the target company. The UK Takeover Code also protects a target company from being hindered in the conduct of its business by a bid for a longer period than is reasonable. ${ }^{27}$ In 2010 , the UK introduced rules in the Takeover Code to control virtual bids. The control mechanism is built on two important pillars that work together-the target's responsibility to make an announcement and the put-up-or-shut-up rule ('PUSU'). ${ }^{28}$ The designated responsibility of the target company to make an announcement gives it the power to control the timing of a bid and bring the bidding process to an early end if the bidder is not prepared to make a firm bid. An announcement by the target triggers a 28-day period for the bidder to make a firm offer. If the bidder chooses not to make a firm offer, it is foreclosed from making another bid for the next 12 months. Thus, virtual bid control provides considerable power to a target company by imposing a tight 28-day deadline on

\footnotetext{
${ }^{23}$ UK Companies Act 2006, s 797(1)(b).

24 The Cabinet Office rejected the proposal for such disenfranchisement because the law-making power belonged to the Ministry of Justice rather than the Ministry of Economy, Trade and Industry (METI).

${ }^{25}$ JASDEC also notifies the company of the identity of particular shareholders who will exercise their minority rights to the company.

26 The $5 \%$ disclosure rule above also applies to those who hold shares under custody's names.

${ }^{27}$ General Principle 6 of the Takeover Code.

${ }^{28}$ City Code on Takeovers and Mergers, Rule 2.4. Additionally, for comments on the deadline, see Helia Ebrahimi, Takeover Panel to Review 'Cadbury Law' (21 October 2012), The Telegraph, available at http://www.telegraph.co.uk/finance/markets/9624417/TakeoverPanel-to-review- Cadbury-law.html.
} 
the bidder. The effect is that unless the bidder has prepared the necessary resources, the target can use its announcement power to bring a takeover battle to an early end by forcing the bidder to confirm its intention to make a bid. ${ }^{29}$ This mechanism also eliminates the potential threat from a bidder because the bidder cannot, alone or acting in concert, make another takeover bid for 12 months. Hence, the PUSU rules can act as a control on the movement of capital or a cost to a bidder. Currently, there is no such control in the EU takeover regime. In Japan, the responsibility for making an announcement rests with the bidder, and there is no equivalent to the PUSU regime. The FIE requires a bidder to make an announcement by serving a public notice in the Official Gazette or in daily newspapers. On the same day as the announcement, the bidder must file a bidder's statement with regulators. Furthermore, it is the bidder's duty to state the duration of the takeover bid, which is usually between 20 and 60 days. The effect is that a bidder has more time to engage in negotiations with the target board and has the power to set the time frame. During such negotiations, the bidder has time to conduct its due diligence as well as to make other preparations for the bid, such as stock pricing. The lack of control on a virtual bid in Japan means that there is less of a burden on, and cost to, the bidder; hence, Japan's framework provides more favourable conditions for a takeover than the UK's regime.

\subsection{Commitment control}

There is increasing concern about a bidder's treatment of a business after taking over. In the UK, a bidder must disclose its intended plan for the business, which has a binding effect on the company. ${ }^{30}$ The plan must include the repercussions on employment, the location of the offeree company's place of business, plans for the redeployment of fixed assets and the maintenance of any existing trading facilities for shares. ${ }^{31}$

The post-takeover business plan was a new requirement introduced after the US company Kraft's takeover of the UK company Cadbury. The Panel issued a posttakeover statement of criticism that asserted that statements made by Kraft regarding the relocation of production after the takeover did not meet the standards of the Code. ${ }^{32}$ Cadbury was planning to move its production facilities to Poland, and Kraft stated that it believed that this move would not occur until the latter part of 2010 and claimed that it would continue to operate the existing production facility (Somerdale facility) for products sold in the UK. However, the factory facility in Somerdale was in fact transferred to Poland in the middle of 2010. The Executive of the Panel held that Kraft's statement was not a

\footnotetext{
${ }^{29}$ The PUSU rule was effectively applied in the case of Pfizer's potential hostile takeover of AstraZeneca. The latter target board's insistent rejection of all potential offers and discussions by the former company up until the PUSU deadline gave Pfizer little room but to 'shut up'.

30 Blanaid Clarke, 'Reviewing Takeover Regulation in the Wake of the Cadbury Acquisition

Regulation in a Twirl', (2011) 3 Journal of Business Law, 300.

${ }^{31}$ City Code on Takeovers and Mergers, Rules 24.2 and 25.1.

32 City Code on Takeovers and Mergers, Rule 19.1.
} 
reasonable belief using an objective test. However, it is not clear what sanctions the Panel can impose to enforce such a commitment. ${ }^{33}$

In Japan, a bidder must, in its TOB statement, describe any plans for corporate reorganisations, material borrowings, changes in member composition, changes in the composition of officers, material changes in the dividend or capital policy, and changes in management policies. ${ }^{34}$ The bidder must state whether the shares are likely to be de-listed after the takeover and, if so, must provide the reasons for that action. The bidder must not give false statements with regard to these matters. A false statement can lead to civil liability for damages, fines and imprisonment. In addition to the details required in the TOB statement, the target board can also request similar information from a bidder. Under the FIE, ${ }^{35}$ the target must file an 'Opinion Report' - to reject or accept a bid-within 10 days after the bidder has filed its TOB statement. In the board's Opinion Report, the board can make more detailed enquiries of the bidder regarding its posttakeover business plan. The bidder must file an 'Answer Report' within 5 business days after the target's filing. ${ }^{36}$ However, the bidder does not have an obligation to make a full and detailed disclosure and can intentionally keep its answers broad and vague.

Unlike the UK regulation's strict binding effect on the bidder, there is no such legal effect of this statement under the FIE. The bidder does not need to honour what is said in the statement if the circumstances require it to change course from its plans disclosed in the statement. Compared with the UK's approach, Japan does not impose a legal duty on a bidder to commit to its plan. The UK's approach, although it cannot be said to have a protectionist tendency, imposes a higher cost on the bidder than what is required in Japan. The EU Directive does not regulate information on post-takeover business plans.

\subsection{Mandatory bid}

The purpose of a mandatory bid is multifaceted, and the context must be analysed to discern the aims of such a regulation. A mandatory bid normally describes an obligation of the bidder to make an offer to purchase shares in a target company when or immediately before the bidder's holding surpasses a certain threshold. Broadly speaking, the aim is to ensure equal treatment of the shareholders of the target company. In addition, a 'control premium' must be paid by the bidder and distributed to the existing shareholders. Without these two conceptual underpinnings of shareholder protection supporting the mandatory bid requirement, a mandatory bid would simply act as an extraordinary burden on and cost to a bidder. This very high cost imposed on a bidder can act as a control on the movement of capital and essentially serves as a protectionist measure in disguise. There has been ongoing debate and extensive

33 City Code on Takeovers and Mergers, Rules 19.7, 19.8 and 24.2.

34 The FIE, Article 27-9.

35 The FIE, Article 27-10-1,2.

36 The FIE, Article 27-10-11. 
discussion regarding whether the US model of non-mandatory bids or the UK and EU model of mandatory bids increases corporate performance, investor protection, and capital market efficiency. Japan's mandatory bid regulation presents a very different story. Japan requires a bidder to make an actual bid before crossing the threshold of 30 per cent shareholding of the target. ${ }^{37}$ This ex ante requirement is different from the UK's ex post requirement. ${ }^{38}$ The aim of Japan's mandatory bid regulation is to ensure transparency in the transfer of control of a company so that the board of the target company, the market, and the regulators are notified of such a change in control. The two conceptual underpinnings of shareholder protection regarding mandatory bids in the UK and EU do not form the foundation for Japan's ex ante 30 per cent mandatory bid requirement. The remaining shareholders do not receive a control premium paid by the bidder, as the mandatory bid does not require the bidder to make a mandatory purchase of the remaining shares. In fact, a partial bid can be made. Another anomaly is that in Japan, a mandatory bid is only required when the transaction is made off the market. On-market purchases are exempt from the mandatory bid requirement ${ }^{39}$, which raises the question of why this exemption applies. In contrast, the UK and EU mandatory bid requirements apply to both on-the-market and off- market purchases. An explanation for this exemption is that purchasing a 30 per cent holding on the market is more expensive than doing so off the market. Furthermore, it is difficult to purchase, unless through stake-building, a 30 per cent holding on the market. The transfer of such a degree of control of a company can be more easily performed through an off-the-market purchase. However, the transfer of 30 per cent control does not effectively lead to control of the acquired company because the appointment of the board directors still requires shareholder approval by more than 50 per cent of the total shares. At best, a 30 per cent holder can appoint some directors to the board. This exemption substantially removes the cost to the bidder imposed under the UK and EU models when acquiring control of a company through an on- market purchase. In other words and in theory, an acquirer can purchase shares in a target company and acquire control by obtaining more than 50 per cent of the shares on the market without making a mandatory bid. However, the foregoing does not support the suggestion that Japan's mandatory bid rule is a disguised protectionist measure. Furthermore, Japan adheres to the one-shareone-vote principle in which major shareholders cannot out-vote others by exercising special voting rights. Therefore, Japan does not need the EU type of breakthrough rule to resolve special voting rights issues that can act as an obstacle to a takeover.

There is another mandatory bid requirement under the FIE. Once a person acquires more than 75 per cent of a target's outstanding shares, a mandatory bid must be made. ${ }^{40}$ This mechanism essentially represents a bidder's buy-out obligation and the existing shareholders' sell-out rights. A partial bid is not

\footnotetext{
37 The threshold is provided by the Ordinance 14-2-2 under Article 27-13-4 of the FIE.

38 Tomotaka Fujita 'The Takeover Regulation in Japan: Peculiar Developments in the Mandatory Offer Rule' (2011) No3 UTSoft Law Review 24-41.

${ }^{39}$ However, after-hours on the market transactions made through ToSTNet and J-Net are not exempted. See FIE, Article 27-2-.13.

40 The FIE, Article 27-13-4.
} 
allowed; however, there is no regulation of the offering price. Thus, a bidder can make a mandatory bid below the market price. A 75 per cent shareholder has more than effective control of a company, and such a mandatory bid does not serve the purpose of offering a control premium to the remaining shareholders, nor does it serve as a substantial protection to them. Had there been a price control on the offer-such as the highest price at which the bidder has acquired shares in the past few months-this mandatory requirement could serve as a measure to protect the remaining shareholders. In the absence of this price control element, however, this requirement effectively provides a convenient tool for a bidder to obtain full control without incurring a high cost for minority shareholder protection.

A conclusion that can be drawn from these findings is that the 30 per cent and 75 per cent mandatory bid requirements do not represent a more substantial cost to the bidder than the mandatory bid requirements under the UK and EU models. Mandatory bids in Japan cannot be used as protectionist measures in disguise against a takeover bid; they only restrict the opportunities of minority shareholders to benefit from a takeover. Because transfers of control often take place within a corporate group of companies, the 30 per cent ex ante rule serves as a transparency measure. When such information is disclosed, an outsider to the group can make an unsolicited bid.

\subsection{Defensive measures}

With regards to the most debated area of defensive measures, Japan's system is no more of an innovative legal design than the frameworks in the UK, the EU or the US. The UK's non-frustration rule vests the power to raise defences in the shareholders. The power of management to use defences as a protectionist measure or as a genuine tool to protect shareholders from being coerced to accept an under-valued offer has been greatly diminished by the non-frustration rule. Increasingly, the non-frustration rule benefits short-term-focused investor groups, such as hedge funds and private equity firms. The activities of these entities are vital to the interests of the City of London as the world financial centre. By contrast, the EU's opt-out rule continues to allow companies to raise defences. To level the playing field, the reciprocal rule, if opted-in by the member state, can be used by companies to raise defences against a takeover by a company from a country without such a non-frustration rule. Japan has largely adopted the Delaware approach based on the Unocal case ${ }^{41}$. Under the Japanese approach $^{42}$, the board has the power to raise defences to protect corporate value. ${ }^{43}$ The term 'corporate value' was subsequently interpreted in a

\footnotetext{
41 Unocal Corp. v. Mesa Petroleum Co., 493 A.2d 946 (Del. 1985).

42 In NBS $v$ Livedoor, the court has developed the case law by interpreting 'unfair issue of shares/ share option' in ruling whether or not poison pills used may be unfair under company law provisions so as to allow shareholders of the company to obtain injunction of the issue under the Articles 210 and 247 of the Companies Act.

43 D. Hugh Whittaker and Masaru Hayakawa, 'Contesting “Corporate Value” Through Takeover Bids in Japan’ (2007) 15(1) Corporate Governance 16-26.
} 
government-commissioned report by a study group as the monetary interests of existing shareholders. ${ }^{44}$ This 'business judgement rule' does not allow the board to use defences to protect a board-favoured takeover deal even in the interest of the company. As in the NBS case ${ }^{45}$, the court ruled against the defence of a shareholder rights plan (a 'poison pill') that the target company's board adopted to protect a takeover bid made by its own subsidiary. The target board believed that such a takeover bid by its own subsidiary would benefit the target company by creating more business synergies. This case demonstrates that even in a takeover within a corporate group, the courts had no problem ruling out any measures that would prevent an outsider from acquiring control of an entity within that corporate group. Similarly, in the famous Bull-Dog Sauce case ${ }^{46}$, the Tokyo Supreme Court further confirmed the shareholder primacy rule and allowed a defence raised by the target board against an active US private equity fund. In allowing the defence, the Supreme Court reasoned that the rights plan was approved by an overwhelming majority of the shareholders at the general meeting. It disagreed with the rulings by the Tokyo District Court and the Tokyo High Court. Both lower courts focused more on the conduct of the bidder-both specifically in this takeover and more generally regarding the business model and strategy of Steel Partners. Specifically, Steel Partners had refused to disclose its post-takeover business plan as requested by the target board in the target's 'Opinion Report'. More generally, Steel Partners had acquired an infamous reputation for not respecting the Japanese value of corporate community-that is, requiring that management focus on the corporate long-term vision as opposed to short-term gain. Japan's system is no more legally uncertain than that of Delaware or an EU member state opting out of the non-frustration rule. The Tokyo Supreme Court's ruling is effectively a non-frustration rule. The question is why shareholders would approve defensive measures both pre-bid and postbid. The more interesting aspect, however, is how companies use pre-bid defences to monitor the potential threat of a takeover.

Japanese companies often adopt a pre-warning type of defence that requires a bidder to comply with the target's demands. ${ }^{47}$ The target company can issue a notice requesting that a suspected bidder observe the procedure designed by the target. Such a notice is normally issued even before a bid becomes imminent, for instance, when a person's shareholding passes the 15 per cent threshold. The bidder can be required to disclose its acquisition plan and submit information such as a business plan. If the suspected bidder fails to comply with the procedure imposed by the target, that failure can trigger a rights plan that allows the company to issue shares to its members and exclude the suspected bidder. Such a defence gives the target the power to monitor any potential threat and to control a 'virtual bid'. It is also a power given to the target board to repeatedly request information from a potential bidder. This pre-warning type of defence

\footnotetext{
${ }^{44}$ Masatsugu Yoshioka 'A comparative critique of cash-out mergers in Japan and the US' (2005) 5(2) Journal of Corporate Law Studies 465-506.

45 NBS v. Livedoor, 1899 Hanrei Jihô 56 (Tokyo High Court, March 23, 2005).

46 Bull Dog Sauce v. Steel Partners 2007 Tokyo Supreme Court, Case No. 2007 (Kyo) 30

${ }^{47}$ For a detailed discussion of its use, see Appendix C 'Advance Warning Poison Pill' in Encrio Colcera The Market For Corporate Control in Japan: M\&As, Hostile Takeovers and Regulatory Framework (Springer Heidelberg 2007).
} 
involves a rights plan that authorises the board to issue shares, usually in the form of share options, once certain conditions have been met. Such a defence is not used in the UK and EU, as the issuance of share capital is more restricted. The UK and EU require shareholder approval for an allotment of shares. The UK, for instance, requires that the board's authority to allot shares be approved and renewed every five years. However, in practice, as recommended by insurance and pension groups, this authority is renewed every year. Japan has no law requiring the board to obtain such shareholder approval. However, many companies voluntarily obtain shareholder approval of a rights plan for a period of 3 years or, in some cases, 1 year. In the 2014 amendment to Companies Act, where as a result of new issuance of shares or share options a subscriber is expected to hold a majority of all the issued shares of the company, all the existing shareholders are provided an opportunity to disagree on the new issuance to the subscriber. ${ }^{48}$ When the percentage of dissenting shareholders reaches 10 per cent, a shareholder meeting must be held in order to obtain shareholders' approval. ${ }^{49}$ The question is why shareholders approve such defences. In addition, there is no shareholder pre-emption right in Japan ${ }^{50}$. Hence, shareholders do not receive an immediate monetary gain under such a rights plan. There are an increasing number of cases where shareholders vote down the board's proposal to adopt defensive measures. The factors influencing such changes in attitude amongst shareholder groups should be further investigated.

These regulatory aspects align with the regulatory themes contained in the EU Takeover Directive and the UK Takeover Code. The courts have developed rules-largely following the Delaware Revlon approach-to prevent the board from abusing its power by adopting poison pills when faced with a hostile takeover bid. However, a detailed examination of the FIE will reveal that some of the rules do have the effect of discouraging unsolicited/hostile takeover bids. These rules must also be read in conjunction with the symbiotic relationships between boards and shareholders. These relationships have been created through cross-shareholding with corporate shareholders and through shareholder perks with retail shareholders. ${ }^{51}$

\section{Decreasing cross-shareholding as a 'breakthrough' for takeovers}

\subsection{Decreasing cross-shareholding}

\footnotetext{
48 Companies Act, Article 206-2.

${ }^{49}$ Companies Act, Article 244-2.

50 The law allows the companies to do so on a voluntary basis under Article 202 of the Companies Act. In the UK, a pre-emption right is no longer mandatory in private companies. There is an ongoing debate about the wisdom of such a right for the shareholders in listed companies.

51 Toru Yoshikawa, Philip Phan 'Alternative corporate governance systems in Japanese firms: implications for a shift to stockholder-centered corporate governance' (2001) 18(2) Asia Pacific Journal of Management 183-205.
} 
Cross-shareholding refers to two types of symbiotic relationship between investors and management. ${ }^{2}$ The first refers to banks investing in companies in return for obtaining business, such as selling insurance policies or managing pension funds, but does not involve companies holding shares in the banks that also hold their shares..$^{53}$ The second type of relationship is where companies invest in each another to obtain mutual support. Until recently, crossshareholding constituted 50 per cent of the total shareholding of most of the listed Japanese companies. Cross-shareholdings create a soft alliance whereby there is a tacit understanding, as opposed to a formal contract, that votes should be exercised according to the recommendations of the board. In a takeover, institutional and corporate shareholders who accept a hostile tender offer or vote against the recommendation of the board suffer reputational damagewhich is a vital asset for doing business in Japan. An insurance company, as a result of not following the board's decisions in a takeover, would lose their opportunity to obtain business from the target company as well as from other companies that believe in this 'value'. Cross-shareholding is therefore a non-legal means to control the movement of capital. ${ }^{54}$ Through it, shareholders can be mobilised to successfully fend off a takeover bid. Therefore, a decrease in crossshareholding in Japan should change the voting pattern of shareholders in general meetings. It can also increase the movement of capital, which in turn can lead to changes in the composition of shareholders. When such changes in shareholder composition eventually diminish cross-shareholdings, there will be an increased number of successful unsolicited takeovers. Changing Japan's takeover law to accord with UK or EU norms would not decrease the level of cross-shareholdings in Japanese companies.

The experience in Japan shows that economic and legal measures can be introduced to reduce cross-shareholdings ${ }^{55}$. A requirement to increase banks' equity ratio can achieve this end. Enforcing fiduciary duties to prompt the board to dispose of under-valued cross-holdings is another method. However, the latter would require a more solid legal argument to counter-balance the business judgement rule that favours the board's investment discretion. The government could also use its taxing power to decrease the level of cross-holdings by cutting the corporate capital gains tax to incentivise the disposal of these shares by companies. The competition law could also be used to break up these soft alliances. Although reducing the level of corporate cross-shareholdings and breaking up these soft alliances could provide more space for the free movement of capital, the massive sale of these shares would create a high supply of shares

\footnotetext{
52 Takaya Seki 'Legal reform and shareholder activism by institutional investors in Japan' (2005) 13(3) Corporate Governance 377-385.

$53 \mathrm{~F}$ Hayashi 'The main bank system, and corporate investment: An empirical reassessment' in M Aoki and G Saxonhouse Finance, Governance, and Competitiveness in Japan (Oxford: OUP 2000); Wenlian Gao 'Banks as lenders and shareholders: Evidence from Japan' (2008) 16(4) PacificBasin Finance Journal 389-410.

${ }^{54}$ David Weinstein and Yishay Yafeh 'On the costs of a bank-centered financial system: Evidence from the changing main banks relations in Japan' (1998) 53(2) Journal of finance 635-672.

55 Under Article 308 of the Companies Act, if company A holds at least one fourth of the issued shares of the company B, company B cannot exercise its voting right at shareholder meetings of company A.
} 
without a matching level of demand, which would result in a plunge in share prices. Another way of regulating cross-shareholdings is to require companies to disclose the level of cross-shareholdings in their company. Some Japanese companies have started making such disclosures in their annual reports. ${ }^{56}$ Unless there is a benefit in doing so, however, companies are unlikely to make such a disclosure. ${ }^{57}$

Cross-shareholding raises a number of legal questions about institutional and corporate shareholders' fiduciary duty to their own respective shareholders. ${ }^{58}$ First, by not selling their holdings to the bidder to maximise their monetary returns, boards may be in breach of the fiduciary duty owed to their companies and shareholders. Such a breach is more evident when companies incur losses or when they need to improve their cash flow. With such a legal duty and the bursting of the economic bubble in the mid-1990s, companies have been prompted to sell their cross-holdings-reducing them to 30 per cent. For banks' cross-shareholdings, there has also been a decline from 30 per cent to 12 per cent since the beginning of the 1990s. This decrease has been partly attributed to the requirement that banks increase their capital ratio, which led banks to dispose of their much-devalued shares held in companies.

\subsection{Increasing hedge fund activities}

The increase in private equity funds in Japan has coincided with a decrease in the level of corporate cross-shareholdings. Private equity funds see Japan as a lucrative market for the undervalued stocks of Japanese companies. A number of shareholder activist strategies have been used to create returns on investment. The common investment strategies used include demands for boards to increase dividends, requests to buy back shares, and putting pressure on the board to dispose of under-performing assets. These strategies may have contributed to the acceleration in companies' disposal of cross-shareholdings as illiquid and non-preforming assets. ${ }^{59}$ The realisation of the gains resulting from the disposal of these assets can be used to fund dividend distributions or to finance share buyback programmes to increase shareholder returns. These actions also have the effect of reducing a company's cash reserves, which has been said to create a disincentive for companies to change their governance structure. In the takeover context, a private equity fund can use a takeover bid to obtain benefits from the board as, for example, in the greenmail strategy. In the Bull-Dog Sauce case, Steel Partners submitted a takeover bid and then faced the board's defence of a poison pill. Steel Partners was then excluded from the new issuance of shares under the

\footnotetext{
${ }^{56}$ For instance, Eisai Co., Ltd, a Japanese pharmaceutical company, has disclosed the level of cross-shareholding in their annual report. http://www.eisai.com/pdf/eannual/epdf2014an.pdf 57 The EU Directive on Takeover Bid requires the disclosure of some cross-shareholdings. Article 10(1)(c) of Directive 2004/25EC (Directive on takeover bids).

${ }^{58}$ Recent case law, however, has referred to the directors' duty to shareholders. Rex Holding case, 1301 Kinyû Shôji Hanrei 28 (Tokyo High Court, September 12, 2008); Sunstar case, 1326 Kinyû Shôji Hanrei 20 (Osaka High Court, September 1, 2009).

${ }^{59}$ Hideaki Sakawa, Masato Ubukata, Naoki Watanabe 'Market liquidity and bank-dominated corporate governance: Evidence from Japan' (2014) 31(2) International Review of Economics \& Finance 1-11.
} 
defensive rights plan, but it received a compensatory payment in lieu of the newly issued shares from the company. The payment was upheld by the court as legal, and the payment also justified the discriminatory treatment of Steel Partners by the company. The fate of private equity funds in Japan will depend on them finding continuing funding sources. Leveraged buyouts (LBO) will remain low in Japan, especially if the buyouts are hostile, because banks in Japan-both domestic and foreign-will not finance hostile LBOs for fear of reputational damage. ${ }^{60}$ Because the profit margins of banks remain low, the bargaining power rests with the borrower. If a bank provides a bridge loan to finance a hostile LBO, it will lose other lending business with the target company and its associated companies, i.e. subsidiaries. ${ }^{61}$

\section{Increased corporate governance as another possible 'breakthrough' for takeovers}

\subsection{Independent board}

Independent directors play a role in managing the board's conflicts of interest by reducing the transaction costs in a takeover. ${ }^{62}$ Such conflicts can arise in several ways. For instance, the board of directors may leak information about an immature takeover negotiation to thwart a potential takeover threat. It can issue a negative opinion about a bid or recommend a bid that would mainly benefit certain directors and major shareholders. It can make a request about a bidder's business plan with the aim of increasing the bidder's cost. Independent directors can ensure that these measures are not taken as a way for the directors to entrench their position. The process of obtaining competent independent advice to form the board's opinion about a bid can be monitored by the independent directors. The UK Corporate Governance Code recommends that independent directors do not carry out executive functions or maintain direct connections with the company, for instance, by being major shareholders or shareholder representatives to the company. In Japan, there is a statutory requirement to have at least one independent director on the board. ${ }^{63}$ This requirement operates on a 'comply or explain' basis. In June 2015, a new Corporate Governance Code came into force which requires two independent directors for listed companies ${ }^{64}$. Compared with the requirements of the UK Corporate

\footnotetext{
${ }^{60}$ Kenji Kutsyna, Janet Smith, \& Richard Smith 'Banking relationships and access to equity capital markets: Evidence from Japan's main bank system' (2007) 31(2) Journal of Banking \& Finance 335-360.

${ }^{61}$ Ayoko Yasuda 'Do bank relationships affect the firm's underwriter choice in the corporatebond underwriting market?' (2005) 60 The Journal of Finance 1259-1292.

62 Yoshiro Miwa and Mark Ramseyer 'Who appoints them, what do they do? Evidence on outside directors from Japan' (2005) 14(2) Journal of Economics \& Management Strategy 299-337.

63 The Japanese Companies Act Article 2(15). It defines an independent director as a person (1) who is not an executive director nor an executive officer, nor an employee, including a manager, of such Stock Company or any of its subsidiaries, and (2) who has neither ever served in the past as an executive director nor executive officer, nor as an employee, including a manager, of such Stock Company or any of its subsidiaries.

$64 \quad$ Japan's $\quad$ Corporate $\quad$ Governance $\quad$ Code, $\quad$ Principle $4-8$ http://www.fsa.go.jp/en/refer/councils/corporategovernance/20150306-1/01.pdf
} 
Governance Code, it is questionable whether two independent directors on the board can effectively control the conflicts of interest of the other executives on the board. In fact, the independent director is an anomaly to the collective culture of the Japanese board. An appointed, independent outsider would be required to carry out executive functions and perform an 'advisory' duty rather than a 'monitoring' one. Stemming from the recent 2008 financial crisis, the independent director in UK-listed companies is expected to be in charge of the company's risk management by holding back the executive directors' egos, which can lead to excessive risk taking. Such risk management can also take place in the remuneration committee, in which the independent directors design an appropriate model for executive pay.

Whether such control of pay is an effective method of risk management, and is in a company's best interest in the long term, is questionable. The UK and the West are at one end and Japan is at the other end of the spectrum. The prolonged deflationary economy in Japan is a cause of Japan's risk-averse culture. Not only do Japanese boards not take excessive risks, they do not take what may appear to many Western executives to be reasonable risks. This risk-averse culture can be attributed to the life-long employment model in Japanese companies. Directors are promoted through the ranks of employees. Chairman of the board is often a post for the company's retired CEO. The CEO and the directors do not risk changing the corporate roadmap simply to drive up the share price. By contrast, share price management is an important measure of directors' success in the UK and the West. UK and Western company directors are asked by shareholders to resign for poor performance. Japanese boards do not face the same pressure regarding share performance, and the directors are under no legal and moral obligation to resign. In this way, the government hopes to increase the influence of independent outside directors in acting as catalysts to encourage more risktaking. Independent directors should not be employees of subsidiary companies or cross-held companies. They are not supposed to monitor or supervise the board but should bring their particular management skills to increase corporate performance. However, Japan does not have a large pool of professional executives who normally move from one company to another for short periods. ${ }^{65}$ The likelihood is that more foreign directors will take independent director positions.

The appointment of independent directors and their increased number in a company can reduce conflicts of interest stemming from cross-shareholding and rebalance the power given to executive directors that is reinforced by crossshareholding. In a takeover, the independent directors, who have access to information about the company's cross-shareholdings, are in a better position to identify the interests of minority shareholders. They may be more objective in assessing the company's future prospects when their interest does not lie in the hope of being appointed as the next CEO or Chairman of the board. Not only can they act as a channel between minority shareholders and management, by actively seeking independent external opinions, they will help to create a more

65 The CEO of Lawson moving to Suntory is a rare example; Also see A Horiuchi and K Shimizu 'Did Amakudari undermine the effectiveness of regulator monitoring in Japan' (2001) 25 Journal of Banking and Finance 573. 
balanced and fair board. In this way, the board can issue their 'Opinion Report' based on a more independent assessment.

\subsection{Shareholder protection}

\section{Individual shareholders}

What is most lacking in Japanese shareholder protection mechanisms in the FIE is the equivalent of mandatory bids in the UK and EU that provide shareholders an equal right to share the control premium. The UK mandatory bid requirement benefits minority shareholders and serves the interest of private equity firms' business models. As stated previously, Japanese shareholders tend to support management. ${ }^{66}$ This symbiotic relationship is partly attributed to corporate cross-shareholdings. Individual shareholders, who currently own 18 per cent of the total share capital listed on the TSE, are supportive of management. Many of them are former employees and customers of the companies. They strongly identify with the companies, and therefore, their investments are not mostly profit-driven but are connected to their sentiment of being included within the corporate community. Their investments are largely relational. Management also rewards them with a token of thanks through shareholder discount vouchersshareholder perks. ${ }^{67}$ These vouchers can be exchanged at kiosks for cash. In this way, individual shareholders' sense of community with and loyalty to the company, thus indirectly supporting management, are reinforced through these shareholder perks. This explains why Bull-Dog Sauce, a household name, received overwhelming shareholder support for management's defence against an unsolicited hostile bid by US Steel Partners, which offered a significant premium on the market price.

\section{Institutional shareholders}

How do private equity firms and hedge funds that seek shorter term returns on their investments benefit from shareholder protections? Their interest would be better served in a takeover if the UK and EU types of mandatory bid requirement were imposed at a lower level. Likewise, the Delaware type of shareholder protection could also provide them more opportunities to realise returns. These measures must be supported by stricter control of the non-frustration rule. Shareholders associated through cross-shareholdings that create conflicts of interest with management should also be controlled. This scenario is different from the EU's shareholder agreement where the breakthrough rule is required to momentarily suspend their agreements in a takeover - thus freeing shareholders from these agreements regarding the exercise of their votes on management's defence. As mentioned previously, cross-shareholding in Japan does not create a legal relationship that directs shareholders in the exercise of their votes. The effect of not exercising their votes to support management results in reputational damage, and retaliation by management and the network of

\footnotetext{
${ }^{66}$ Stephanie Pease, Stanley Paliwoda, Jim Slater 'The erosion of stable shareholder practice in Japan' (2006) 15 International Business Review 618-640.

67 B McLannahan 'Japanese shareholders reap quirky perks' Financial Times 23 Feb 2014.
} 
companies would result in reciprocal withdrawals of support. Therefore, one way of protecting minority shareholders could be to require the votes of crossheld shares to be disclosed and, in extreme cases, discounted.

With regard to shareholder perks, the amount distributed should be subject to income tax to avoid a disguised distribution of dividends. As dividends by Japanese companies are below the European average, restricting these perks could increase individual shareholders' efforts to pursue a return on their investment. ${ }^{6}$

\section{Forecasting Japan's market for corporate control}

As stated above, Japan has an active market for mergers and acquisitions. Compared with other advanced economies, it also has an active market for corporate control as measured by the number of takeover bids per year- yet the number of hostile takeovers remains very low. However, bringing Japan to the level of the UK and US markets, where there are a greater number of successful unsolicited takeover bids, will depend not on changes in its existing FIE to align with UK and EU laws, but on structural changes by decreasing crossshareholding. ${ }^{69}$ Independent directors can also bring changes to the symbiotic relationships between management and shareholders. An increase in the number of independent directors and an increase in their supervisory function could put more pressure on management to focus on investor returns. This approach could force management to dispose of undervalued and illiquid crossheld stocks. However, the real pressure for change will have to come from economic pressure. Economic pressure can lead to more radical structural changes. Nevertheless, Japanese companies can find ways to continue their growth by avoiding structural changes. The Bank of Japan can devalue its currency to attempt to create an export-led recovery of Japan's economy, as recently happened..$^{70}$ Japanese companies can also acquire profit-making foreign entities to boost their overall growth, which explains why there have been more in-out buyouts by Japanese companies. Many Japanese companies and banks are also financially strong, ${ }^{71}$ and even if a particular entity within a corporate group is operating at a loss, it will not trigger an unsolicited hostile takeover.

\footnotetext{
${ }^{68}$ Aoki Yasuharu 'How does the largest shareholder affect dividends' (2014) 14(4) International Review Finance 613-645. In Japan, the corporation-owned companies tend to have lower dividends.

69 T Pempel 'Structural gaiatsu: International Finance and Political Change in Japan' (1999) 32(8) Comparative Political Studies 907-932; Glenn Morgan and Izumi Kubo 'Beyond path dependency? Constructing new models for institutional change: the case of capital markets in Japan' (2005) 3 Socio-Economic Review 55-82.

70 TF Cargill, MM Hutchison and Ito Takatoshi Financial Policy and Central Bamking in Japan (MIT Cambridge 2000).

${ }^{71}$ Qi Luo, Toyohiko Hachiya, 'Corporate governance, cash holdings, and firm value' (2005) 8(4) Review of Pacific Basin Financial Markets and Policies 613-636.
} 


\section{Conclusion}

The perceived low level of activity in the Japanese takeover market cannot be attributed to its takeover law, the Financial Instrument or the Exchange Law. Indeed, a careful examination of the content of the law reveals that this legislation operates in the offeror's favour. In contrast with the UK Takeover Code and the EU Takeover Directive, there is no evidence that Japanese takeover law imposes more burdens on the unsolicited offeror. Yet there are structural defences, notably cross-shareholdings, that can frustrate an unsolicited bid and which cannot be removed by an EU-style breakthrough rule. The relationship of individual shareholders with the management is also influenced by the distribution of un-taxed shareholder perks and this helps to explain why individual shareholders tend to support the incumbent management. The conclusion is that seeking a convergence of Japanese takeover law with those of the UK and EU would not remove the barriers to an increased number of successful unsolicited bids in the Japanese takeover market. The general corporate governance norms relating to independent directors and shareholder protection, if aimed at reducing the conflicts stemming from the crossshareholdings, can potentially break through the Japanese corporate control structure. However, the effectiveness of these norms will depend on whether their intended purpose is properly understood and whether shareholders see the benefits of their enforcement. While the government may play a role in carrying out reform measures in order to reduce cross-shareholdings, it is unlikely that government action by itself will be enough to increase competitiveness. And despite recent government action, there is no evidence that reducing cross-shareholdings as a barrier to takeovers is a high priority on the government's reform agenda. 